\title{
From Judicial Independence to Interdependence in the International Sphere
}

\author{
Aida Torres Pérez*
}

\begin{abstract}
The goal of this article is to develop an analytical framework for the conceptualization of international judicial independence. First, it will be argued that judicial independence is not to be conceived as an end in itself but rather as a condition for the legitimacy of international courts (ICs). Also, independence is not a monolithic concept, but one of degree and the optimal degree of independence might vary according to the function and type of ICs. Second, I will provide a taxonomy of judicial independence in the international sphere and identify and systematize the relevant actors and variables. While studies about international judicial independence tend to focus on the mechanisms available to state governments, this work will take into account a broader set of actors and variables. Finally, a notion of interdependence will be advanced as a framework for institutional design that combines the need to enable adjudication free from undue influence or pressure with mechanisms to counterbalance judicial power. Forms of interdependence on the grounds of the principles of accountability and checks and balances might contribute to the overall legitimacy of ICs.
\end{abstract}

Keywords: Judicial Independence; Legitimacy; International Courts; Accountability; Checks and Balances.

\section{§1. Introduction}

Since the end of the Cold War, the number of international courts (ICs) has increased from six to nearly thirty in $2017 .{ }^{1}$ Moreover, the nature of ICs has been

\footnotetext{
* Law Professor at Pompeu Fabra University (Barcelona). I truly thank Armin von Bogdandy, Andreas Follesdal, Barry Friedman, Alejandro Saiz Arnaiz, Neus Torbisco, and the participants in the workshop on the Independence of the International Judiciary (UPF, Barcelona); the Dienstagsrunde at the Max Planck Institute for Comparative Public Law and International Law (Heidelberg); and the Lunch Seminar at iCourts (University of Copenhagen), for challenging questions and illuminating comments.

${ }^{1}$ K.J. Alter, The New Terrain of International Law: Courts, Politics, Rights (Princeton University Press, 2014), p. 68-77; C. Romano, K. Alter and Y. Shany, 'Mapping International Adjudicative Bodies, the Issues, and Players', in C.P.R. Romano, K.J. Alter and Y. Shany (eds.), The Oxford Handbook of International Adjudication (Oxford University Press, 2014).
} 
transformed and multilateral courts with compulsory jurisdiction have proliferated. ${ }^{2}$ The increasing power and influence of ICs has consequently triggered debates surrounding their legitimacy.

The legitimacy of ICs, as institutions vested with the power to adjudicate disputes in accordance with the law, is heavily grounded on their independence. ${ }^{3}$ Judicial independence demands that the judges who apply the law to the disputes brought before them be free from undue pressures or influences from external actors, but what judicial independence means and requires in the international sphere remains somewhat contested. The goal of this article is to contribute to building an analytical framework for determining the notion of international judicial independence.

Judicial independence should not be conceived in absolute terms, since this is neither feasible nor desirable. Adjudication necessarily involves a degree of discretion in the interpretation of the law and it is possible for ICs to contribute to the creation of norms through adjudication. ${ }^{4}$ Additionally, judges might pursue certain policy objectives or strive to expand their own power. Thus, just like any other authority that exercises public power, ICs need to be constrained. And yet, constraining judicial power without undermining judicial independence poses both theoretical and practical difficulties.

Referring to international organizations, Peters has identified a shift in the scholarship from concern about the enabling function of the law (effectiveness) to the constraining function (accountability). ${ }^{5}$ In the context of ICs, while the authority and effectiveness of ICs has dominated the debate, only recently there has there been an increasing concern regarding their accountability, ${ }^{6}$ particularly when ICs become wellestablished. $^{7}$

\footnotetext{
${ }^{2}$ K.J. Alter, The New Terrain of International Law: Courts, Politics, Rights, p. 68-69.

${ }^{3}$ R. Mackenzie and P. Sands, 'International Courts and Tribunals and the Independence of the International Judge', 44 Harvard International Law Journal (2003), p. 271-285; J. Crawford and J. McIntyre, 'The Independence and Impartiality of the "International Judiciary"', in S. Shetreet and F. Forsyth (eds.), The Culture of Judicial Independence (Martinus Nijhoff Publishers, 2012).

${ }^{4}$ S. Besson, 'Getting over the Amour Impossible between International Law and Adjudication', in C.P.R. Romano, K.J. Alter, Y. Shany (eds.), The Oxford Handbook of International Adjudication.

${ }^{5}$ A. Peters, 'International Organizations: Effectiveness and Accountability', MPIL Research Paper Series 1 (2016), https://papers.ssrn.com/sol3/papers.cfm?abstract_id=2770606, p. 1.

${ }^{6}$ D. Shelton, 'Legal Norms to Promote the Independence and Accountability of International Tribunals', 2 The Law and Practice of International Courts and Tribunals (2003), p. 27-62; P. Mahoney, 'The International Judiciary - Independence and Accountability', 313 The Law and Practice of International Courts and Tribunals (2008), p. 313-349.

${ }^{7}$ See, A. Follesdal, 'Independent yet Accountable: Stress Test Lessons for the European Court of Human Rights', 24 Maastricht Journal of European and Comparative Law (2017).
} 
First, it will be argued that judicial independence is not to be conceived as an end in itself, but rather as a condition for legitimacy. Also, independence is not a monolithic concept, but one of degree. ${ }^{8}$ The optimal degree of independence might vary according to the function and type of ICs.

Second, I will provide a taxonomy of judicial independence in the international sphere and identify and systematize the relevant actors and variables. While studies about international judicial independence tend to focus on the mechanisms available to state governments, this work will take into account a broader set of actors and variables.

Finally, a notion of interdependence will be advanced as a framework for institutional design that combines the need to enable adjudication free from undue influence or pressure with mechanisms to counterbalance judicial power. Forms of interdependence on the grounds of the principles of accountability and checks and balances might contribute to the overall legitimacy of ICs.

\section{§2. Judicial Independence as a Condition of Institutional Legitimacy}

Judicial independence should not be conceived as an end in itself, but as a necessary (and not sufficient) condition of the legitimacy of ICs. One might distinguish between a normative and a sociological notion of legitimacy. ${ }^{9}$ In a normative sense, legitimacy refers to the conditions or reasons that justify the claim of authoritativeness. Normative legitimacy aims to determine why the law or a particular institution should be obeyed.

In a descriptive or sociological sense, following Weber, ${ }^{10}$ legitimacy implies that a legal system or institution is perceived as legitimately binding by those under its jurisdiction, and thus making a justified claim to obedience. In this sense, legitimacy, as an empirical fact, solely reflects an attitude held by individuals. In the words of Tyler, '[1]legitimacy is a psychological property of an authority, institution, or social arrangement that leads those connected to it to believe that it is appropriate, proper, and just. Because of legitimacy, people feel that they ought to defer to decisions and rules,

\footnotetext{
8 S.B. Burbank and B. Friedman, 'Reconsidering Judicial Independence', in S.B. Burbank and B. Friedman (eds.), Judicial Independence at the Crossroads. An Interdisciplinary Approach (Sage Publications, 2002).

${ }^{9}$ A. Follesdal, 'The Legitimacy Deficits of the Human Rights Judiciary: Elements and Implications of a Normative Theory', 14 Theoretical Inquiries in Law (2013), p. 339-360; M.R. Madsen, 'Sociological Approaches to International Courts', in C.P.R. Romano, K.J. Alter and Y. Shany (eds.), The Oxford Handbook of International Adjudication.

${ }^{10}$ M. Weber, Economy and Society (I) (Bedminster Press, 1968), p. 31.
} 
following them voluntarily out of obligation rather than out of fear of punishment or anticipation of reward'. ${ }^{11}$

In this context, it is important to distinguish (normative or sociological) legitimacy from compliance (or authority in a descriptive sense). Compliance is an empirical notion that indicates whether the rules or decisions issued by an institution are obeyed by those to whom the rules or decisions are addressed.

The normative and sociological notions of legitimacy are not unrelated, since an institution that fulfils the conditions for normative legitimacy might enhance social legitimacy in terms of perception. In addition, both normative and sociological legitimacy might promote compliance. ${ }^{12}$

This work will mainly focus on independence as a necessary condition for (normative) legitimacy, rather than inquiring on the perceptions of actors regarding the legitimacy and independence of ICs. Still, in order to gain support from key constituencies, courts not only need to be independent, but must also be perceived as independent since '[n]ot only must Justice be done; it must also be seen to be done'.

The legitimacy of ICs, furthermore, may well also be contingent on other factors, such as democratic rule ${ }^{13}$ or effectiveness. ${ }^{14}$ This notwithstanding, judicial independence lies at the core of the justification of the courts' power to adjudicate, in a way that is distinct from the power exercised by other public authorities, such as the legislative or the executive powers.

Given the diversity of ICs in terms of their type and functions, the desirable degree of independence might vary. With regard to domestic courts, Shapiro ${ }^{15}$ drew a link between judicial independence and the transition from arbitration to adjudication. As the argument goes, the arbitration model is premised upon the consent of the parties, who may choose the law being applied and the arbitrators. The legitimacy of such tribunals is perceived as stemming directly from the disputing parties’ consent. Shapiro observed that as societies became more complex, there was a shift from arbitration to adjudication, and they tended to substitute 'law and office' for consent. As such, parties no longer had a choice, and both the law and the judge were provided by the state. He

11 T. Tyler, 'Psychological Perspectives on Legitimacy and Legitimation', 57 Annual Review of Psychology (2006), p. 375-400, 375.

12 Ibid.

${ }^{13}$ A. von Bogdandy and I. Venzke, In Whose Name? A Public Law Theory of International Adjudication (Oxford University Press, 2014).

${ }^{14}$ Y. Shany, Assessing Effectiveness of International Courts (Oxford University Press, 2014).

${ }^{15}$ M. Shapiro, Courts. A Comparative and Political Analysis (University of Chicago Press, 1981). 
claimed that 'the substitution of law and office for consent entailed major destabilizing pressures on the triadic structure' for conflict resolution. Courts could then be seen as an ally of one of the parties, or as representing a new, third interest, that of the legal regime itself. It is in the context of this shift that judicial independence became a primary source of legitimacy.

At the international level, to some extent, there has also been a shift from arbitration to adjudication (or from consent to 'law and office') as a consequence of the creation of permanent courts with compulsory jurisdiction within multilateral regimes, such as the European Court of Human Rights (ECtHR), the Court of Justice of the European Union (CJEU) or the International Criminal Court (ICC). Also, individuals have gained access to several ICs, whose jurisdiction, therefore, is no longer limited to disputes between states. Judicial independence thus becomes crucial for the claim of legitimate authority. This is not to say that independence is not important in the context of international arbitration, but it probably is and should be understood differently, focusing instead on the lack of conflicts of interest, rather than on institutional considerations.

Independence is not a monolithic concept, but one of degree, and the desirable level of independence could well vary across courts. What are then relevant criteria that determine the desirable level of independence for the distinct types of courts? The degree of independence may well be associated, first, to the functions exercised by ICs. Their functions have diversified and are no longer limited to dispute settlement, but also now involve securing norm-compliance, the maintenance of cooperative international arrangements, monitoring the exercise of national and international authority, lawmaking and legitimization of the authority exercised by others. ${ }^{16}$

Second, the structure of and access to ICs is also a relevant element in determining the optimal degree of independence and the corresponding mechanisms to safeguard judicial independence since international adjudicative bodies range from nonpermanent arbitral bodies for commercial or investment disputes to permanent courts with compulsory jurisdiction. ${ }^{17}$ Over time, individuals and other non-state parties have gained access to ICs and at present inter-state courts are in the minority, such as the

\footnotetext{
${ }^{16}$ Y. Shany, 'No Longer a Weak Department of Power? Reflections on the Emergence of a New International Judiciary', 20 European Journal of International Law (2009), p. 73-91; A. von Bogdandy and I. Venzke, In Whose Name? A Public Law Theory of International Adjudication, p. 5-17; K.J. Alter, The New Terrain of International Law: Courts, Politics, Rights.

${ }^{17}$ C.P.R. Romano, K.J. Alter and Y. Shany, in C.P.R. Romano, K.J. Alter and Y. Shany (eds.), The Oxford Handbook of International Adjudication.
} 
International Court of Justice (ICJ) and the World Trade Organization Appellate Body (WTO AB), ${ }^{18}$ and hence the audiences and demands for independence vary. In the end, given the growing institutionalization of ICs, judicial independence thus becomes crucial for the claim of legitimate authority.

\section{§3. A Taxonomy of Judicial Independence in the International Sphere}

In a seminal article in 2003, Mackenzie and Sands put forward the question regarding the applicability of judicial independence to ICs and the appropriate standards of judicial independence in an international setting. ${ }^{19}$ They asserted that judicial independence was a significant factor in maintaining the credibility and legitimacy of ICs and tribunals, while leaving the second part of the question unanswered.

Some authors have cast doubt on the notion of international judicial independence. Most notably, Posner and Yoo claimed that dependent ICs were more effective. $^{20}$ Their argument, however, was powerfully contested by Helfer and Slaughter, who strived to explain why it might be in the states' interest to set independent ICs. They argued that delegating authority to independent ICs serves the interests of the states to the extent that delegation enhances the credibility of their international commitments. ${ }^{21}$ They formulated a theory of 'constrained independence' according to which states establish independent international tribunals to enhance the credibility of their commitments in specific multilateral settings and then use more finegrained structural, political and discursive mechanisms to limit the potential for judicial overreaching. Even although they mainly focused on mechanisms in the hands of state governments, and their approach was largely descriptive, rather than normative, the notion of 'constrained independence' will be retained for the purposes of the next section.

The concept of judicial independence is widely used and highly elusive, and there is little agreement on what judicial independence is or how much judicial independence is required in the international sphere. Actually, at the international level, there are several declarations and standards about judicial independence addressed to domestic courts, but only one refers explicitly to the international judiciary: the Burgh

\footnotetext{
${ }^{18}$ Ibid., p. 12.

${ }^{19}$ R. Mackenzie and P. Sands, 44 Harvard International Law Journal (2003).

${ }^{20}$ E.A. Posner and J.C. Yoo, 'Judicial Independence in International Tribunals', 93 California Law Review (2005), p. 1-74.

${ }^{21}$ L.R. Helfer and A.M. Slaughter, 'Why States Create International Tribunals: A Response to Professors Posner and Yoo’, 3 California Law Review (2005), p. 1-58, 33-34.
} 
House Principles On The Independence Of The International Judiciary. According to these principles, independence requires that: '[t]he court and the judges shall exercise their functions free from direct or indirect interference or influence by any person or entity'.22

One can distinguish between independence as a normative ideal and independence as a feature of the institutional setting within which judicial decisionmaking takes place. ${ }^{23}$ As a normative ideal, independence requires that judges take decisions free from undue influences or pressures from other actors that might distort the performance of the judicial function. From an institutional perspective, we strive to capture and understand the rules and practices that contribute to shielding the decisionmaking process from undue influences, or, more generally, that demarcate the space for free decision-making. ${ }^{24}$

The notions of independence and impartiality tend to be used interchangeably, but theoretically they need to be distinguished. ${ }^{25}$ On the face of it, impartiality encapsulates the notion of the judge as a neutral third. Impartiality is understood as the lack of interest or bias with regard to the parties or the object of the case. ${ }^{26}$ Independence refers to a set of institutional and other factors to ensure that judges take decisions free from the influences and pressures of other actors. ${ }^{27}$

In that regard, we can also distinguish studies on judicial independence and judicial behaviour. Political science and sociological studies on judicial behaviour examine the factors that determine why international judges behave the way they do, which might include biases in terms of nationality, geopolitics or other political and

\footnotetext{
${ }^{22}$ The Burgh House Principles On The Independence Of The International Judiciary were formulated by The Study Group of the International Law Association on the Practice and Procedure of International Courts and Tribunals, in association with the Project on International Courts and Tribunals. The Mt. Scopus Approved Revised International Standards of Judicial Independence (March 19, 2008), approved by the International Association of Judicial Independence and World Peace, contain a section on minimum standards for the independence of the international judiciary based, with minor amendments, on the Burgh House Principles.

${ }^{23}$ J. Ferejohn, 'Independent Judges, Dependent Judiciary: Explaining Judicial Independence', 72 Southern California Law Review (1998-1999), p. 353-384.

${ }^{24}$ Y. Shany, Assessing the Effectiveness of International Courts, p. 99; E. Voeten, 'International Judicial Independence', in J.L. Dunoff and M.A. Pollack (eds.), Interdisciplinary Perspectives on International Law and International Relations (Cambridge University Press, 2013), p. 421-422.

${ }^{25}$ See, P. Pasquino, 'Prolegomena to a Theory of Judicial Power: The Concept of Judicial Independence in Theory and History', 2 The Law and Practice of International Courts and Tribunals (2003), p. 11-25, independence is a means to impartiality.

${ }^{26}$ J. Crawford and J. McIntyre, in S. Shetreet and F. Forsyth (eds.), The Culture of Judicial Independence; Y. Shany, Assessing the Effectiveness of International Courts, p. 97-101.

${ }^{27}$ E. Voeten, in J.L. Dunoff and M.A. Pollack (eds.), Interdisciplinary Perspectives on International Law and International Relations.
} 
institutional motivations, as well as other social factors, such as gender, religion, or culture. ${ }^{28}$ When judges are biased and the reasons for decision-making are extraneous to the merits of the case, their impartiality is thereby jeopardized.

Voeten claims that it is important to 'avoid conflating institutional safeguards with behavioural output. Institutional control mechanisms could affect behaviour but the extent to which they do is a matter of theoretical and empirical debate'. ${ }^{29}$ Indeed, the fact that a judge has been selected by a state government does not necessarily mean that the judge will be influenced or pressured by that government in deciding specific cases, or that the judge will make the national interest prevail no matter what. Still, the method of judicial selection might generate the appearance of bias and might in practice be used to exert influence upon the judge. The capacity of the judge to influence the decision will depend on her leverage within the court and collegiality dynamics. ${ }^{30}$ In any event, the legitimacy of the court suffers not only when judges follow the preferences of other actors, but also when judges reach decisions following their own interests, prejudices or biases.

While the literature on domestic judicial independence is vast, the study of international judicial independence is a relatively new phenomenon, and one might be tempted to approach ICs in light of a domestic frame of reference. And yet, given the diverging institutional and political frameworks, the notions and mechanisms developed at the domestic level cannot be automatically transposed to the international sphere. ${ }^{31}$ In that regard, the role of state consent regarding the creation of international courts, the acceptance of their jurisdiction, and compliance with their decisions; the lack of a structure for the separation of powers, and the diversity of ICs need to be taken into account when approaching international judicial independence. ${ }^{32}$

\footnotetext{
${ }^{28}$ E. Voeten, 'International Judicial Behavior', in C.P.R. Romano, K.J. Alter and Y. Shany (eds.), The Oxford Handbook of International Adjudication; M.A. Pollack, 'Political Science and International Adjudication', in C.P.R. Romano, K.J. Alter and Y. Shany (eds.), The Oxford Handbook of International Adjudication; N. Grossman, 'Achieving Sex-Representative International Court Benches', 110 American Journal of International Law (2016), p. 82-95; N. Torbisco, 'International Court and Culture: Identity Conflicts and the Limits of Litigation', 24 Maastricht Journal of European and Comparative Law (2017).

${ }^{29}$ E. Voeten, in J.L. Dunoff and M.A. Pollack (eds.), Interdisciplinary Perspectives on International Law and International Relations, p. 424.

${ }^{30}$ See S. Turenne, 'Institutional Constraints and Collegiality at the Court of Justice of the European Union: A Sense of Belonging?', 24 Maastricht Journal of European and Comparative Law (2017).

${ }^{31}$ P. Mahoney, 7 Law and Practice of International Courts and Tribunals (2008), p. 316-318; J. Crawford and J. McIntyre, in S. Shetreet and F. Forsyth (eds.), The Culture of Judicial Independence, p. 190-191.

${ }^{32}$ A. Torres Pérez, 'In Nobody's Name: A Checks and Balances Approach to International Judicial Independence', MPIL Research Paper Series 3 (2017), http://ssrn.com/abstract=2924435, p. 4-14.
} 
In this context, how should international judicial independence be operationalized? What are the relevant actors and variables that can be identified to assess the independence of ICs? In general, current attempts to operationalize judicial independence at the international level overly focus on the process of judicial selection and the role of state governments.

A number of political scientists have employed the principal-agent theory ${ }^{33}$ to argue that control mechanisms retained by state governments over ICs reduce the scope of their independence. Such accounts have not gone unchallenged, and others have claimed that ICs are better understood as trustees. ${ }^{34}$ At the same time, sociological and neofunctionalist approaches have emphasized the role of other domestic and supranational actors in defining the space for judicial decision-making. ${ }^{35}$

In the international sphere, the sources of potential influence and interference upon courts include a variety of national, supranational, and international actors of a diverse nature. ${ }^{36}$ Since the national and the international spheres are increasingly intertwined, a multilevel and disaggregated approach will be followed. The array of national and international actors can be classified in four main groups:

1) Political institutions: state governments are regarded as the main threat to judicial independence, since they are responsible for the design of ICs, they tend to retain mechanisms of institutional control and moreover have the capacity to act at the international or supranational level through intergovernmental institutions.

Also, ICs might also be constrained by the political institutions and other bodies of the international organizations in which they operate. These bodies might well vary in nature: intergovernmental or parliamentary bodies, different types of commissions, or international prosecutors. For instance, in the context of the Inter-American system, the role of the Inter-American Commission is worthy of attention since it is for the Commission to decide whether a case will be brought before the Inter-American Court of Human Rights (IACtHR) and thus has the power to set the Court's agenda.

\footnotetext{
${ }^{33}$ See E. Voeten, in J.L. Dunoff and M.A. Pollack (eds.), Interdisciplinary Perspectives on International Law and International Relations; M.A. Pollack, in C.P.R. Romano, K.J. Alter and Y. Shany (eds.) The Oxford Handbook of International Adjudication.

${ }^{34}$ K.J. Alter, 'Agents or Trustees? International Courts in their Political Context', 14 European Journal of International Relations (2008), p. 33-63.

${ }^{35}$ K.J. Alter and L. R. Helfer, 'Nature or Nurture? Judicial Lawmaking in the European Court of Justice and the Andean Court of Justice', 64 International Organization (2010), p. 563-592; E. Voeten, in J.L. Dunoff and M.A. Pollack (eds.), Interdisciplinary Perspectives on International Law and International Relations; M. Madsen, in C.P.R. Romano, K.J. Alter and Y. Shany (eds.), The Oxford Handbook of International Adjudication.

${ }^{36}$ D. Zimmermann, The Independence of International Courts (Nomos, 2014).
} 
2) Courts: the sources of influence and constraint might come from actors pertaining to the internal court administration, encompassing judges with administrative capacity (the President and Vice-President); or administrative officials and other personnel (such as the registrar and law clerks). Also, ICs might influence each other in various ways. Competition among ICs might effectively serve as a constraint on international judicial power. ${ }^{37}$ Cross-references and judicial dialogue might promote judicial cooperation and independence from other actors, but also become a source of epistemic dependence. ${ }^{38}$ Finally, domestic courts might become a source of dependence regarding the enforcement or broader effectiveness of ICs. ${ }^{39}$

3) Litigants: potential influences or pressures from the parties are better captured by the notion of impartiality, rather than through the lens of independence. Impartiality demands neutrality towards the parties and the object of the dispute. Yet, in the case of ICs, one should bear in mind that very often at least one of the parties will be a state.

4) Civil society: the role of diverse stakeholders, such as NGOs or commercial actors, ${ }^{40}$ needs to be taken into account in relation to distinct ICs. For instance, the role of NGOs both in the negotiations to establish the ICC and in the operation of this court has been widely discussed. ${ }^{41}$ More generally, the role of legal elites and public opinion in influencing ICs or acting as an external audience that can react to the curtailment of judicial independence should not be overlooked. ${ }^{42}$ Indeed, who the relevant actors are and how much weight they carry might vary across courts.

In addition, there is a multiplicity of variables that are relevant from the perspective of judicial independence, either in terms of shielding ICs from influence or constraining their action. Several authors have identified specific factors that can condition judicial independence in practice, such as the scope of legal discretion and

\footnotetext{
37 J.K. Cogan, 'Competition and Control in International Adjudication', 48(2) Virginia Journal of International Law (2008), p. 411-449.

${ }^{38}$ L.R. Helfer and A.M. Slaughter, 'Toward a Theory of Effective Supranational Adjudication', 107 Yale Law Journal (1997), p. 273-391; G.L. Neuman, 'Import, Export, and Regional Consent in the InterAmerican Court of Human Rights', 19 European Journal of International Law (2008), p. 101-123; O. Saldías, ‘¿Refugiándose en redes epistémicas? El Tribunal de la Comunidad Andina y la independencia judicial', in M. Hernández, M. Zelaia and A. Torres Pérez (eds.), Tribunales en Organizaciones de Integración: MERCOSUR, Comunidad Andina y Unión Europea (Aranzadi, 2012).

${ }^{39}$ K.J. Alter and L. Helfer, 64 International Organization (2010).

${ }^{40}$ E. Voeten, in C.P.R. Romano, K.J. Alter and Y. Shany (eds.), The Oxford Handbook of International Adjudication.

41 Z. Pearson, 'Non-Governmental Organizations and the International Criminal Court: Changing Landscapes of International Law', 39 Cornell International Law Journal (2006), p. 243-284.

42 J.L. Cavallaro and S.E. Brewer, 'Reevaluating Human Rights Litigation in the Twenty-First Century: The Case of the Inter-American Court', 102 The American Journal of International Law (2008), p. 768827; A. Vauchez, 'Communities of International Litigators', in C.P.R. Romano, K.J. Alter and Y. Shany (eds.), The Oxford Handbook of International Adjudication.
} 
control over material and human resources; ${ }^{43}$ diverse formal and political mechanisms, ex ante and ex post; ${ }^{44}$ threats of non-compliance and legislative override; ${ }^{45}$ or interstate and inter-branch competition. ${ }^{46}$

Drawing from the existing legal and political science literature, the relevant variables for judicial independence ${ }^{47}$ can be grouped in the following dimensions:

1) The structural dimension refers to the composition of the court, which includes the process of judicial selection and appointment, and the presence of 'national judges' on the bench. ${ }^{48}$ Judicial selection is of paramount importance in evaluating the independence of ICs, and indeed this element has been central to the debates. ${ }^{49}$

2) The personal dimension encapsulates an array of variables, such as: tenure and reappointment; the regime of incompatibilities, conflicts of interests, and disqualifications; privileges and immunities; judicial discipline and removal; salaries, pensions, and other entitlements. The lack of life tenure puts judges in a vulnerable position if they are able to anticipate the negative consequences of their decisions and thus personal protections become particularly relevant in the context of ICs.

3) The procedural dimension includes elements related to judicial procedure and reasoning. The rules and practices involving standing and other forms of intervention (third party intervention, amicus curiae) may affect the independence of ICs. ${ }^{50}$ To the extent that individuals have standing, states lose control over the kind of cases that reach the court and the court's audience consequently broadens. Individual access

\footnotetext{
${ }^{43}$ R.O. Keohane, A. Moravcsik and A.M. Slaughter, 'Legalized Dispute Resolution: Interstate and transnational', 54 International Organization (2000), p. 457-488.

${ }^{44}$ L.R. Helfer and A.M. Slaughter, 93 California Law Review (2005); T. Ginsburg, 'Political Constraints on International Courts', in C.P.R. Romano, K.J. Alter and Y. Shany (eds.), The Oxford Handbook of International Adjudication.

${ }^{45}$ C.J. Carrubba, M. Gabel and C. Hankla, 'Judicial Behavior under Political Constraints: Evidence from the European Court of Justice', 102 American Political Science Review (2008), p. 435-452; contested by A. Stone Sweet and T.L. Brunell, 'The European Court of Justice, State Noncompliance, and the Politics of Override', 106 American Political Science Review (2012), p. 204-213.

${ }^{46}$ E. Benvenisti and G.W. Downs, 'Prospects for the Increased Independence of International Tribunals', 12 German Law Journal (2011), p. 1057-1081.

${ }^{47}$ Regarding the variables to measure judicial independence see, S. Voigt, 'The Independence of International Courts: Making Reputation Work?', 24 Maastricht Journal of European and Comparative Law (2017) and G. Dimitropoulos, 'Measuring Judicial Independence in International Law: Putting Together the Pieces of the Puzzle, 24 Maastricht Journal of European and Comparative Law (2017).

${ }^{48}$ See L. López Guerra, 'National Judge and Judicial Independence: The Case of the Strasbourg Court', 24 Maastricht Journal of European and Comparative Law (2017).

${ }^{49}$ See M. Bobek (ed.), Selecting Europe's Judges. A Critical Review of the Appointment Procedures to the European Courts (Oxford University Press, 2015); R. Mackenzie et al., Selecting International Judges: Principle, Process, and Politics (Oxford University Press, 2010).

${ }^{50}$ L.R. Helfer and A.M. Slaughter, 93 California Law Review (2005); S. Voigt, J. Gutmann and L.P. Feld, 'Economic growth and judicial independence, a dozen years on: Cross-country evidence using an updated set of indicators', 38 European Journal of Political Economy (2015), p. 197-211.
} 
increases the opportunities and expectations of independence. Moreover, the rules and practices regarding the decision-making process, encompassing collegiality, deliberations, and dissenting opinions, are also relevant in terms of independence.

4) The organizational dimension refers to the administrative organization and financing of the court. The administrative organization of the court includes the functions attributed to the court's President for the internal managing of the docket, such as the allocation of cases, or the assignment of judges to the chambers. ${ }^{51}$ In practice, the use that Presidents make of their discretion might become a relevant source of internal influence. In addition, the registry provides legal and administrative support to the court. The procedures for selecting the registrar and for recruiting law clerks, and their role (for instance, in the drafting of judgments) are also key to understanding internal sources of influence. Yet, these features tend to go unnoticed. ${ }^{52}$ Finally, the source and allocation of resources, meaning both the financial means at the court's disposal to perform its functions and possible interference with the overall budget, could condition the court's capacity to operate independently.

5) The compliance dimension not only includes the actual enforcement of international judgments, but also threats to change the rules by amending the respective treaty (or the rules of procedure), or even threats to withdraw from the court's jurisdiction. Since ICs do not enjoy enforcement powers, prospects of non-compliance, override, and exit might have an influence on adjudication, particularly with regard to sensitive cases. ${ }^{53}$ Usually these features are regarded as mechanisms to exert influence on the court ex post, after a judgment has been issued, but they might also have an ex ante effect, if the IC anticipates this sort of conduct on the basis of past experience. Thus, provisions and practices that make non-compliance, override and exit more difficult might foster the independence of ICs. ${ }^{54}$

Regarding each dimension, the relevant variables need to be approached both from a de iure and a de facto perspective, where de iure independence refers to the

\footnotetext{
${ }^{51}$ T. Meron, 'Judicial Independence and Impartiality in International Criminal Tribunals', 99 American Journal of International Law (2005), p. 359-369.

${ }^{52}$ S. Cartier and C. Hoss, 'The Role of the Registries and Legal Secretariats in International Judicial Institutions', in C.P.R. Romano, K.J. Alter and Y. Shany (eds.), The Oxford Handbook of International Adjudication.

53 J. Ríos-Figueroa and J.K. Staton, 'An Evaluation of Cross-National Measures of Judicial Independence', 30 The Journal of Law, Economics, and Organization (2014), p. 104-137.

${ }^{54}$ E. Voeten, in J.L. Dunoff and M.A. Pollack (eds.), Interdisciplinary Perspectives on International Law and International Relations.
} 
written rules and de facto independence to the practice. ${ }^{55}$ Hence, the analysis of the several variables for each ICs ought not to be limited to the legal rules governing ICs, but rather seek to unveil the ways in which the legal rules are operationalized in practice.

Having identified the main actors and dimensions that are relevant from the perspective of judicial independence, one could map the web of interactions between actors and variables for each IC. Indeed, this correlation may well vary across ICs given their inherent diversity.

\section{§4. From Judicial Independence to Interdependence}

The indeterminacy of the law, in particular international law, requires much interpretation, affording judges a wide margin of discretion. No one disputes that ICs are often presented with cases that leave room for discretion in identifying and interpreting the law. Additionally, international adjudication might involve checking the action of democratic States. Moreover, judges often contribute to the creation of norms through adjudication. ${ }^{56}$ As Besson put it, the problems of judicial discretion and lawmaking are magnified in the international sphere. ${ }^{57}$

Hence, the power of ICs, as any institution that exercises public authority, needs to be counterbalanced to prevent ICs from overstepping their boundaries and avoid the feared 'government of judges'. At the same time, there is a risk that constraining mechanisms will be used in such a way as to subject ICs to the arbitrary will of others. ICs that are too dependent are equally as problematic as courts that are too independent. ${ }^{58}$ In the end, the legitimacy of ICs requires establishing a balance between judicial independence and power constraints.

Judges do not operate in a vacuum and their decisions might be influenced by multiple factors, ranging from what the judge had for breakfast to her political or religious beliefs. As argued above, judicial independence requires that judges take decisions free from undue influences or pressures from other actors that might distort the performance of the judicial function. Hence, independence does not demand that judges be free from any influence or constraint, but only from those influences or

\footnotetext{
${ }^{55}$ L.P. Feld and S. Voigt, 'Economic Growth and Judicial Independence: Cross Country Evidence Using a New Set of Indicators', 19 European Journal of Political Economy (2003), p. 497-527.

${ }^{56}$ A. von Bogdandy and I. Venzke, In Whose Name? A Public Law Theory of International Adjudication.

57 S. Besson, in C.P.R. Romano, K.J. Alter and Y. Shany, The Oxford Handbook of International Adjudication.

${ }^{58}$ See A. Follesdal, 24 Maastricht Journal of European and Comparative Law (2017).
} 
constraints that might distort the decision-making process by including considerations extraneous to adjudication or which might create an appearance of bias. ${ }^{59}$

The fact that ICs are institutionally 'dependent' on other institutions to develop their functions should not be rejected outright. There are forms of interdependence between courts and other institutions and actors that might be justified. The notion of interdependence refers to constraining mechanisms coming from other actors to prevent the court from overstepping its powers. Whether those forms of institutional interdependence curtail judicial independence will be determined by how those mechanisms are used in practice. ${ }^{60}$ It is a question, hence, of the principles that might justify forms of institutional and political constraint.

Next, I will examine the principles of accountability and checks and balances. Although both are aimed at constraining power, they are conceptually different. Grant and Keohane found that checks and balances 'are mechanisms designed to prevent action that oversteps legitimate boundaries by requiring the cooperation of actors with different institutional interests to produce an authoritative decision'. ${ }^{61}$ By way of contrast, accountability mechanisms operate ex post, as they enable an assessment of the actions of power-wielders against the corresponding standards and impose sanctions. Constraints on the basis of those principles may well be conceived as forms of interdependence that enhance the overall legitimacy of ICs.

\section{A. Judicial accountability}

Accountability has become a buzzword in both national and international spheres. Indeed, there are as many definitions as there are authors. Broadly, the notion of accountability is associated with good governance and involves a relationship in which the power-wielders are evaluated by those who are affected by their actions or those who entrusted them with power. ${ }^{62}$ In the global realm, given the democratic deficits of global institutions, scholars have turned their attention towards accountability as a

\footnotetext{
59 A. Torres Pérez, 'Can Judicial Selection Secure Judicial Independence? Constraining State Governments in Selecting International Judges’, in M. Bobek (ed.), Selecting Europe’s Judges. A Critical Review of the Appointment Procedures to the European Courts, p. 184.

60 J. Ferejohn, 72 Southern California Law Review (1998-1999), p. 355.

${ }^{61}$ R.W. Grant and R.O. Keohane, 'Accountability and Abuses of Power in World Politics', 99 American Political Science Review (2005), p. 29-43, 30.

${ }^{62}$ Ibid., distinguishing between participation and delegation models of accountability.
} 
source of legitimacy. ${ }^{63}$ Decision-makers' accountability has been regarded as essential in securing the legitimacy of international lawmaking. ${ }^{64}$

Accountability can be understood in a broad or more restrictive way. Bovens distinguished two main notions of accountability: as a virtue and as a mechanism. As a virtue, accountability is used as a normative concept, as a set of standards for the behaviour of actors. As a mechanism, accountability involves 'a relationship between an actor and a forum, in which the actor has an obligation to explain and to justify his or her conduct, the forum can pose questions and pass judgment, and the actor may face consequences'. ${ }^{65}$ We will retain this distinction in analysing judicial accountability.

The notion of accountability is even more elusive when applied to courts, and poses challenges from both a conceptual and practical perspective. What does judicial accountability entail? What standards ought to be applied? To whom should judges be accountable to? There is a variety of actors to whom judges potentially could be held to account: court presidents or senior judges, judicial councils, state governments, international institutions, litigants and the public at large.

In this context, there is a tension between two conflicting values: the independence of judges as adjudicators and their accountability as actors that exercise discretionary power. $^{66}$ Holding judges to account might interfere with their independence, if they can anticipate negative consequences on the basis of their decisions. In this field, we need to proceed with caution since, as Geyh puts it, 'the peril of leaving judicial accountability ill-defined is that it can be co-opted and misused more easily'. 67

In an effort to reconcile the tension between independence and accountability, these principles have been presented as the two sides of the same coin. ${ }^{68}$ While at the

\footnotetext{
63 J. Ferejohn, 'Accountability in Global Context', International Law and Justice Working Papers 5 (2007), http://www.iilj.org/wp-content/uploads/2016/08/Ferejohn-Accountability-in-a-Global-Context2007-2.pdf.

${ }^{64}$ A.M. Slaughter, 'The Accountability of Government Networks', 8 Indiana Journal of Global Legal Studies (2001), p. 347-367; J. Delbruck, 'Exercising Public Authority Beyond the State: Transnational Democracy and/or Alternative Legitimation Strategies?', 10 Indiana Journal of Global Legal Studies (2003), p. 29-43; B. Kingsbury, N. Krisch and R.B. Stewart, 'The Emergence of Global Administrative Law', 68 Law and Contemporary Problems (2005), p. 15-61.

65 M. Bovens, 'Two Concepts of Accountability: Accountability as a Virtue and as a Mechanism', 33 West European Politics (2010), p. 946-967.

${ }^{66}$ M. Shapiro, Courts. A Comparative and Political Analysis, p. 34.

${ }^{67}$ C.G. Geyh, 'Rescuing Political Accountability from the Realm of Political Rhetoric', 56 Case Western Reserve Law Review (2006), p. 911-935, 912.

68 S.B. Burbank, 'Judicial Independence, Judicial Accountability, and Interbranch Relations', 95 The Georgetown Law Journal (2007), p. 909-927; J. Ferejohn and L.D. Kramer, 'Independent Judges,
} 
domestic level there is an increasing interest in judicial accountability, ${ }^{69}$ the notion has scarcely been examined with regard to ICs. ${ }^{70}$ It is generally accepted that accountability also applies to ICs, but, as it will be shown, the instruments to hold judges accountable in that ambit are limited, given the specificities of the international sphere.

In that regard, what constraints on ICs might be justified in terms of accountability without putting their independence at risk? In a strict sense, accountability involves setting standards for judicial conduct and the corresponding oversight mechanisms. More broadly, judicial accountability requires giving reasons in order to support judicial decision-making and can also be associated with transparency.

\section{Statute of international judges and codes of conduct}

If accountability is understood as a mechanism to hold judges to a set of standards and impose sanctions or other consequences, one would need to answer the following questions: what are the standards against which judges may be held accountable? What are the consequences that might follow? To whom should international judges be accountable? Through which processes?

The corresponding standards tend to be set by the respective constitutive international treaty, the statute of the court, the rules of procedure, and increasingly in codes of conduct or ethics. Usually, the court's statute and the rules of procedure include norms regarding the regime of incompatibilities to hold office and conflicts of interests that disqualify the judges from hearing a case. ${ }^{71}$

These norms might also include other duties, such as loyalty, the secrecy of deliberations, ${ }^{72}$ the obligation to disclose any other activities, ${ }^{73}$ a ban on revealing facts

\footnotetext{
Dependent Judiciary: Institutionalizing Judicial Restraint', 77 New York University Law Review (2002), p. 962-1039.

${ }^{69}$ D. Kosar, Perils of Judicial Self-Government in Transitional Societies (Cambridge University Press, 2016).

${ }^{70}$ D. Shelton, 2 Law and Practice of International Courts and Tribunals (2003); P. Mahoney, 313 Law and Practice of International Courts and Tribunals (2008); J. Crawford and J. McIntyre, in S. Shetreet and F. Forsyth (eds.), The Culture of Judicial Independence.

${ }^{71}$ Articles 4 and 18 of the Consolidated version of Protocol (No. 3) on the Statute of the Court of Justice of the European Union, [2010] OJ C 83/210; Rules 4 and 28 of the Rules of Court of the European Court of Human Rights of 14 November 2016; Articles 40-41 of the Rome Statute of the International Criminal Court, A/CONF.183/9.

${ }^{72}$ Article 2 of the Consolidated version of Protocol (No. 3) on the Statute of the Court of Justice of the European Union.

${ }^{73}$ Rule 4 of the Rules of Court of the European Court of Human Rights.
} 
or information that judges have acquired in the performance of their duties or that are sub judice or the abuse of judicial office to obtain unwarranted favourable treatment. ${ }^{74}$

Also, these norms might include standards regarding diligence and professional performance. The ICC Rules of Procedure and Evidence are particularly prolific, and distinguish among 'serious misconduct', 'serious breach of duty', and 'misconduct of a less serious nature'. ${ }^{75}$ For instance, a 'serious breach of duty' is defined as gross negligence in the performance of one's duties or knowingly acting in contravention of those duties, such as where the judge '[r]epeatedly causes unwarranted delay in the initiation, prosecution or trial of cases, or in the exercise of judicial powers' ${ }^{76}$

Over time, courts have enacted codes of conduct and ethics, which specify the standards regarding independence, impartiality, and other duties. For instance, in 2017, the CJEU enacted a new Code of Conduct that further specifies the requirement of independence, the disclosure of financial interests and the prohibitions regarding external activities. ${ }^{77}$ Moreover, it addresses the personal conduct of judges in extrajudicial settings, such as restraint regarding their expressions and the duties after cessation of office. ${ }^{78}$ Moreover, the codes of conduct or ethics might include standards regarding professional performance, such as the ICC Code of Judicial Ethics, which sets forth that judges shall perform all judicial duties properly and expeditiously, and that judges shall deliver their decisions and any other rulings without undue delay. ${ }^{79}$

In general, the standards included in these documents are addressed to secure independence and impartiality or to avoid conducts that might impair the appearance of independence and impartiality. At the same time, some provisions are aimed at promoting diligence, competence, efficiency or other professional standards. ${ }^{80}$ Actually, at the domestic level, standards concerning the organization of the judicial work have become increasingly important. New public management theories have emphasized the importance of effectiveness, efficiency and a client-oriented approach of the judicial

\footnotetext{
${ }^{74}$ Rule 24 of the ICC Rules of Procedure and Evidence, (Official Records of the Assembly of States Parties to the Rome Statute of the International Criminal Court, First session, New York, 3-10 September 2002).

${ }^{75}$ Rules 24 and 25 of the ICC Rules of Procedure and Evidence.

${ }^{76}$ Rule 24 of the ICC Rules of Procedure and Evidence.

${ }^{77}$ Code of Conduct for Members and former Members of the Court of Justice of the European Union, [2016] OJ C 483/1.

${ }^{78}$ Articles 7 and 9 of the Code of Conduct for Members and former Members of the Court of Justice of the European Union.

${ }^{79}$ Article 7 of the ICC Code of Judicial Ethics, ICC-BD/02-01-05.

${ }^{80}$ A. Siebert-Fohr, 'International Judicial Ethics', in C.P.R. Romano, K.J. Alter and Y. Shany (eds.), The Oxford Handbook of International Adjudication.
} 
organization. Nonetheless, managerial forms of accountability are much less developed with regard ICs. ${ }^{81}$

Understood as a mechanism, accountability entails consequences for those who are held accountable in the form of sanctions (or rewards). ${ }^{82}$ Regarding ICs, the sanction available tends to be the most egregious one: removal from office, besides disqualification in the case of conflicts of interest. Less stringent sanctions for misconduct, however, appear to be underdeveloped. ${ }^{83}$

In this context, the ICC stands out. The ICC Rules of Procedure and Evidence distinguish among several types of misconduct from more to less serious and design a set of disciplinary measures accordingly. In addition to removal for cases of serious misconduct or serious breach of duty, the ICC Statute foresees other disciplinary measures for misconduct of a less serious nature. ${ }^{84}$ The Rules of Procedure and Evidence specify that the disciplinary measures that may be imposed are: a reprimand or a pecuniary sanction that may not exceed six months of the salary paid by the Court to the person concerned. ${ }^{85}$

At the same time, the standards set by the codes of conduct and ethics are not enforceable as such, and they do not provide for any sanctions. In this sense, the ICC Code of Judicial Ethics clearly sets forth that the principles embodied in the Code shall serve as guidelines and that they are advisory in nature. ${ }^{86}$ Yet, the CJEU Code of Conduct stipulates that the President of the CJEU, assisted by a Consultative Committee, shall be responsible for ensuring the proper application of the Code. ${ }^{87}$

Finally, to whom are international judges accountable? This is a very sensitive question, since the accountability holder might act in a manner that undermines independence. Moreover, the standards against which judges may be held accountable afford a wide margin of interpretation.

At the national level, in several European countries, judicial councils have been assigned oversight functions on the judiciary to bolster external judicial independence,

\footnotetext{
${ }^{81}$ P. Mahoney, 313 Law and Practice of International Courts and Tribunals (2008), p. 344.

${ }^{82}$ D. Kosar, Perils of Judicial Self-Government, p. 35-36

${ }^{83}$ Article 6 of the Consolidated version of Protocol (No. 3) on the Statute of the Court of Justice of the European Union provides for the possibility of depriving judges of their right to a pension or other benefits.

${ }^{84}$ Articles 46-47 of the Rome Statute of the International Criminal Court.

${ }^{85}$ Rule 32 of the ICC Rules of Procedure and Evidence.

${ }^{86}$ Article 11 of the ICC Code of Judicial Ethics.

${ }^{87}$ Article 10 of the Code of Conduct for Members and former Members of the Court of Justice of the European Union.
} 
and constrain the power of the executive regarding judicial career and discipline. ${ }^{88}$ In the international sphere, judicial councils are lacking. ${ }^{89}$ Usually, the judges themselves (the court's President or the court as a collective body) are in charge of accountability mechanisms, often in combination with the political institutions of the corresponding international organization.

For instance, in the CJEU, the decision on removal, deprivation of pension or other benefits corresponds to the unanimous opinion of the Judges and Advocates General of the CJEU. ${ }^{90}$ The Statute only requires that the decision must be communicated to the Presidents of the European Parliament, the Commission, and the Council. In contrast, in the IACtHR, the Organization of American States (OAS) General Assembly is granted the disciplinary authority over the judges, but it may exercise that authority only at the request of the Court itself, ${ }^{91}$ and thus the General Assembly may not act unilaterally.

In the ICC, there is a mixed model. The President is competent to deal with complaints for misconduct, assisted by one or more judges appointed on the basis of automatic rotation $^{92}$ and has the authority to impose disciplinary measures. ${ }^{93}$ Yet, in the event of a request for removal, the question will be put to vote at the Court's plenary session and, in the case of a recommendation of removal (by a two thirds majority), the final decision is left to the Assembly of States Parties (which must also be passed by a two-thirds majority). ${ }^{94}$

Hence, the enforcement of standards tends to be left to the judges themselves, or at least the initiative is. While this fact might create a risk of corporate solidarity, it has been argued that 'strong methods of oversight by external monitors are vulnerable to abuse and raise the spectre of interference with judicial independence'. ${ }^{95}$ In the end, the

\footnotetext{
${ }^{88}$ D. Kosar, Perils of Judicial Self-Government.

${ }^{89}$ M. Bohlander, 'Separation of Powers and the International Judiciary - A Vision of Institutional Judicial Independence in International Law', in S. Shetreet and C. Forsyth (eds.), The Culture of Judicial Independence, p. 275-278, has advocated for introduction of a permanent General Council of the International Judiciary with functions over budget administration, judicial discipline, recruitment and promotion of judges and a system for continuing professional development.

${ }^{90}$ Article 6 of the Consolidated version of Protocol (No. 3) on the Statute of the Court of Justice of the European Union.

91 Article 20 of the Statute of the Inter-American Court of Human Rights (Adopted by the General Assembly of the OAS, Bolivia, October 1979 (Resolution No.448).

${ }_{92}$ Rule 26 of the ICC Rules of Procedure and Evidence.

${ }^{93}$ Rule 30 of the ICC Rules of Procedure and Evidence.

94 Rule 29 of the ICC Rules of Procedure and Evidence; Article 46(2) of the Rome Statute of the International Criminal Court.

95 D. Terris, C. Romano and L. Swigart, The International Judge: An Introduction to the Men and Women who Decide the World's Cases (Oxford University Press, 2007).
} 
room for accountability (as a mechanism) of international judges is quite narrow, and constraints in terms of accountability might be understood in the context of the personal statute of judges and the court's administrative internal organization.

\section{The requirement to give reasons}

In a broad sense, accountability requires that authorities give reasons for the exercise of power. ${ }^{96}$ In the case of judges, the obligation to give reasons is inherent to the judicial function. In adjudicating cases, judges need to show how the law has been interpreted and applied to the specific case. Indeed, reason-giving is a requirement for the right to a fair trial, according to which judicial decisions need to be properly motivated. Moreover, judicial reasoning is not only relevant vis-à-vis the parties to the case, but also for the public at large, since ICs hold the ultimate authority in interpreting the respective international treaties, which usually include indeterminate clauses that afford judges a wide margin of discretion.

The court needs to engage with all the arguments advanced by the parties and show how they have been carefully weighted and fully answered to avoid any suspicion of bias. Moreover, the judicial arguments can be scrutinized by the public at large, and by legal experts and scholars, whom develop critical analyses of judgments. The obligation to give reasons constrains judicial action in such a way that advances the institutional legitimacy of the court (or might detract from it, if the reasoning is flawed).

In this context, there is an ongoing discussion regarding the allowance of dissenting opinions in ICs. The situation varies across ICs. While, usually, international judges have the possibility of issuing dissenting opinions, such as in the ICJ ${ }^{97}$ and the ECtHR, ${ }^{98}$ dissenting opinions are not allowed in the CJEU, ${ }^{99}$ and only in anonymous form in the WTO AB. ${ }^{100}$ Dissenting opinions are usually supported from the perspective of judicial reasoning and transparency. ${ }^{101}$ From an internal perspective, the possibility of being confronted with a dissenting opinion might foster the clarity and sharpness of

\footnotetext{
${ }^{96}$ J. Ferejohn, IILJ Working Paper 5 (2007).

${ }^{97}$ Article 57 of the Statute of the International Court of Justice; Article 45(2) of the European Convention on Human Rights (ECHR),

${ }_{98}$ Article 45(2) of the ECHR.

${ }^{99}$ Article 36 of the Consolidated version of Protocol (No. 3) on the Statute of the Court of Justice of the European Union.

100 Article 17(11) of Understanding on Rules and Procedures Governing the Settlement of Disputes (Annex 2 of the WTO Agreement).

${ }^{101}$ R.B. Ginsburg, ‘The Role of Dissenting Opinions’, 95 Minnesota Law Review (2010), p. 1-8, 3.
} 
the arguments of the majority. ${ }^{102}$ Indeed, it has been argued that the at times cryptic reasoning of the CJEU is due to the lack of dissenting opinions and the need to reach a compromise among judges that might have different positions regarding the outcome (or might agree with the outcome, but not the reasoning). From an external perspective, the fact that the judges in the minority have the chance to offer their arguments enables the litigants and the public to better understand the terms of the debate. Also, dissenting opinions might anticipate a shift in the case law.

At the same time, the main argument against dissenting opinions is the risk of undermining the authority of the court. ${ }^{103}$ This argument is formulated from the perspective of the civil law tradition, in which courts are expected to speak the law (in one voice). The rulings need to be presented as incontrovertible interpretations of the text. The lack of divisions foster the perception of the law as an undisputed mandate and thus disagreements ought not to be disclosed.

Without now entering into the debate regarding the impact of dissenting opinions on the authority of the court, dissenting opinions might expose international judges and jeopardize their independence, in particular vis-à-vis the state of nationality. If dissenting opinions are not allowed, the position of individual judges will remain unknown. When dissenting opinions are allowed, judges might fear 'retaliation' for issuing opinions against the interests of the respective state; or might decide to make a strategic use of dissenting opinions. In any event, given the lack of tenured judges in ICs, the ban on dissenting opinions might contribute to shielding the independence of the court from an institutional perspective, but it detracts from transparency and accountability.

\section{Transparency}

The principle of transparency has gained momentum as a condition for good governance. Transparency actually facilitates the operation of accountability mechanisms by providing relevant information, but it is not an accountability

\footnotetext{
102 Ibid.

${ }^{103}$ See the discussion in A. von Bogdandy and I. Venzke, In Whose Name? A Public Law Theory of International Adjudication, p. 177.
} 
mechanism as such. ${ }^{104}$ Transparency could rather be regarded as a form of accountability as 'virtue', that is a normative standard for judicial action.

In the judicial ambit, transparency might be valued for different reasons. First, transparency enables public scrutiny of the judicial activity, which might thereby enhance public confidence. In this way, transparency might bolster the democratic legitimacy of courts. ${ }^{105}$

Also, since ICs are further removed than national courts, it has been argued that ICs need public attention in order to enhance their effectiveness and authority, in particular the attention of the individuals and groups that are the potential beneficiaries of their action. ${ }^{106}$ Attention to the work of ICs might be triggered by NGOs, journalists or academics, who might contribute to enhancing public awareness. Transparency might further public debate, including critical attitudes towards the work of ICs. ${ }^{107}$ Indeed, criticism takes part of an open public debate.

In addition, transparency might actually act as a counterweight to the 'dependence' on governments or the political institutions of the corresponding international organizations. ${ }^{108}$ Thus, transparency might contribute to downplaying some of the potential constraints coming from external actors, by promoting forms of interdependence among other actors or the public at large. For instance, regarding the court's composition, a transparent process of judicial selection might bolster judicial independence by publicly revealing the connections between judicial candidates and the governments that proposed them, as well as facilitating scrutiny by other actors. Mechanisms to enhance the transparency of the selection process might include public announcements in newspapers, the specialized press, or on the internet, consultation with civil society organizations, or public hearings before parliamentary or advisory bodies. ${ }^{109}$ Indeed, greater transparency could consequently result in both the selection of more independent judges and greater legitimacy in the eyes of the public.

\footnotetext{
${ }^{104}$ D. Kosar, Perils of Judicial Self-Government, p. 102.

105 A. von Bogdandy and I. Venzke, In Whose Name? A Public Law Theory of International Adjudication.

${ }^{106}$ D. Terris, C.P.R. Romano and L. Swigart, The International Judge: An Introduction to the Men and Women who Decide the World's Cases, p. 171.

${ }^{107}$ Opinion of Advocate General Bobek in Case C-213/15 P Commission v. Breyer, EU:C:2016:994, para. 99-102.

${ }^{108}$ P. Mahoney, 313 Law and Practice of International Courts and Tribunals (2008), p. 346.

109 A. Alemanno, 'How Transparent is Transparent Enough?: Balancing Access to Information Against Privacy in European Judicial Selections’, in M. Bobek (ed.), Selecting Europe’s Judges.
} 
Transparency can also be applied to judicial action. Regarding the judicial process, the statutes of several ICs, such as the ICJ ${ }^{110}$ and ICC, ${ }^{111}$ explicitly provide for the publicity of oral proceedings, but in others confidentiality prevails, such as in the context of the WTO, ${ }^{112}$ particularly at the panel stage. ${ }^{113}$ At the very least, the WTO AB reports are disclosed to the public, and they contain summaries of the submissions of the parties. The transparency of public court proceedings renders public debate possible, critical appraisal of what happens before the court and public discussion, which contributes to constraining judicial action, while enhancing confidence and legitimacy. ${ }^{114}$

At the same time, the general rule is the secrecy of deliberations, ${ }^{115}$ and there are good reasons for confidentiality regarding the internal deliberations. Judges can freely discuss the arguments, without any sort of pressure. Some have advocated for at least limited forms of transparency regarding the decision-making process since that 'could open up new possibilities and constraints of action with democratic potential that are worth exploring'. ${ }^{116}$ Yet, in this field, the independence costs might outweigh the transparency benefits.

The judgments of ICs are rendered publicly available, which is key for transparency and accountability, since the reasons for the outcome are publicly exposed. The availability of dissenting opinions also bolsters the transparency of the court's reasoning, as discussed above.

Regarding access to court's documents, the practice varies. At the ECtHR, the Rules of Court provide that all documents deposited with the Registry

by the parties or by any third party in connection with an application (...) shall be accessible to the public in accordance with arrangements determined by the Registrar, unless the President of the Chamber, for the reasons set out in paragraph 2 of this Rule,

\footnotetext{
${ }^{110}$ Article 46 of the ICJ Statute.

${ }^{111}$ Article 64(7) of the Rome Statute of the International Criminal Court.

${ }^{112}$ Article 17(10) of the Understanding on Rules and Procedures Governing the Settlement of Disputes.

113 A.von Bogdandy and I. Venzke, In Whose Name? A Public Law Theory of International Adjudication, p. $173-174$.

114 A. Alemanno and O. Stefan, 'Openness at the Court of Justice of the EU: Toppling a Taboo', 51 Common Market Law Review (2014), p. 97-140.

${ }^{115}$ Article 54(3) of the ICJ Statute.

${ }^{116}$ A. von Bogdandy and I. Venzke, In Whose Name? A Public Law Theory of International Adjudication, p. 176.
} 
decides otherwise, either of his or her own motion or at the request of a party or any other person concerned. ${ }^{117}$

Thus, a general rule of transparency is followed by several exceptions. In the ICJ, it is stated that the Court may decide that copies of the pleadings and documents annexed thereto will be made accessible to the public on or after the opening of oral proceedings, but only after ascertaining the views of the parties. ${ }^{118}$

In the context of the CJEU, the access to court's documents is currently under debate as a consequence of the Opinion of Advocate General Bobek in Commission v. Breyer. ${ }^{119}$ While the CJEU falls outside the scope of application of Regulation (EC) No. 1049/2001, ${ }^{120}$ Article 15(3) TFEU extended the right to access to documents to the CJEU, but only when exercising 'administrative tasks' ${ }^{121}$ Administrative tasks can be broadly understood as those including internal organization and human resources management (such as the process of appointing the Registrar, or information regarding the court staff), but the line separating judicial and administrative tasks is far from clear cut. $^{122}$

Advocate General Bobek took a step further in his Opinion, ${ }^{123}$ and claimed that even if the Court is exempt from the right of access to documents in so far as its judicial tasks are concerned, the Court remains subject to the principle of openness. He argued that the degree of openness was not optimal and made a distinction between internal and external judicial documents. ${ }^{124}$ While internal documents pertain to the process of judging and ought not to be disclosed, access to external documents, such as the pleadings submitted by the parties or the requests for preliminary references, ought to be granted. Should the CJEU follow the Advocate General's Opinion, the degree of transparency would significantly improve.

\footnotetext{
${ }^{117}$ Article 33(1) of the ECtHR Rules of Court; Article 40(2) of the ECHR.

118 Article 53 of the ICJ Rules of Court.

119 Opinion of Advocate General Bobek in Case C-213/15 P Commission v. Breyer.

${ }^{120}$ Regulation No. 1049/2001/EC of the European Parliament and of the Council of 30 May 2001 regarding public access to European Parliament, Council and Commission documents, [2001] OJ L $145 / 43$.

${ }^{121}$ Decision of the Court of Justice of the European Union of 11 December 2012 concerning public access to documents held by the Court of Justice of the European Union in the exercise of its administrative functions, [2013] OJ C 38/2.

${ }^{122}$ A. Alemanno and O. Stefan, 51 CMLRev. (2014).

${ }^{123}$ Opinion of Advocate General Bobek in Case C-213/15 P Commission v. Breyer.

${ }^{124}$ Ibid., para. 126-128. Internal documents are those 'drafted within the court and for the court', such as the preliminary report of the reporting judge, or the notes for deliberation; and external documents are those 'drafted by the Court for the purpose of the Court's judicial communication with external bodies (...) or those submitted by third parties to the Court in judicial proceedings'.
} 
In the end, transparency enables scrutiny by a broad range of actors and enhances the openness and responsiveness of the institution to the citizens. ${ }^{125}$ While increased transparency and public scrutiny might create risks of public pressure for specific outcomes, it might as well promote independence of ICs vis-à-vis powerful actors in the international sphere.

\section{Checks and balances}

The emergence and evolution of judicial independence is tied to the principle of the separation of powers. In the Spirit of Laws, Montesquieu claimed the need to separate the judicial function from the legislative and executive in order to protect liberty. ${ }^{126}$ In American constitutional thought, the separation of powers was understood in a more flexible and dynamic way according to the doctrine of checks and balances. As Madison claimed in the Federalist Papers: 'Ambition must be made to counteract ambition'. ${ }^{127}$ He went on to explain that the separation of powers 'does not require that the legislative, executive, and judiciary departments should be wholly unconnected with each other' and held that 'unless these departments be so far connected and blended as to give to each a constitutional control over the others, the degree of separation (...) essential to a free government, can never in practice be duly maintained'. ${ }^{128}$ According to the doctrine of checks and balances, each branch of government ought to exercise the assigned function, while they mutually collaborate and monitor each other to prevent the other branches from overstepping their powers. ${ }^{129}$

In the American tradition, judicial independence is understood in light of the principle of checks and balances. Ferejohn argued that judicial independence was rooted in the structural protections afforded by the Constitution, which instituted a complex set of interdependencies among the major branches of power 'aimed at providing the means for each branch of the federal government to protect itself against encroachments by the others'. ${ }^{130}$ Regarding the judiciary, he stated that 'the dependence of the judiciary on the

\footnotetext{
125 B. De Witte, 'Democratic Adjudication in Europe: How can the European Court of Justice be responsive to the citizens?', in M. Dougan, N. Nic Shuibhne and E. Spaventa (eds.), Empowerment and Disempowerment of the European Citizen, (Hart Publishing, 2012).

${ }^{126}$ Montesquieu, The Spirit of the Laws (Book 11, Cambridge University Press, 1989), p. 157.

${ }^{127}$ Madison No. 51, The Federalist Papers (Mentor, 1961)

${ }^{128}$ Madison No. 48, The Federalist Papers.

${ }^{129}$ S. Shetreet, 'The Normative Cycle of Shaping Judicial Independence in Domestic and International Law: The Mutual Impact of National and International Jurisprudence and Contemporary Practical and Conceptual Challenges', 10 Chicago Journal of International Law (2009), p. 275-332, 302.

130 J. Ferejohn, 72 Southern California Law Review (1998-1999), p. 357.
} 
political branches is not a constitutional accident. Rather, it fits within the broader federalist scheme of making the major departments of government interdependent rather than establishing a strict separation of powers' ${ }^{131}$ Hence, judicial independence does not entail isolating the judiciary. Judges are required to decide free from undue pressures and thus adequate protections need to be put in place, while the judiciary is embedded in a web of interdependencies with other branches of power under the checks and balances principle.

The transition from the national to the international sphere casts doubts regarding the application of the principle of checks and balances to the interactions between ICs and other authorities, since the international sphere lacks an institutionalized system of checks and balances enshrined in an overarching constitutional structure.

Nonetheless, we should not so fast discard the principle of checks and balances as a regulative ideal. In a globalized world, the national and the international have become increasingly intertwined. State constitutions no longer regulate the exercise of power within the territory of the state in a comprehensive way, but rather they need to be complemented with norms deriving from other sources to obtain an overall picture of the regulation of the exercise of power and its limits. Indeed, global constitutionalism 'advocates for the application of constitutional principles in the international sphere in order to improve the effectiveness and fairness of the international legal order'. ${ }^{132}$

The argument here is that judicial independence should not be sought through the insulation of ICs (even if that were possible), and that constraints on ICs can be justified in light of the checks and balances principle in order to prevent abuses. The principle of checks and balances thus contributes to delimiting the space for free judicial decision-making, which cannot and should not be unlimited.

In this vein, we need to consider which national or international institutions might provide an appropriate check or balance to the power of ICs, which interests and values those institutions might represent, and what the adequate mechanisms for implementing those constraints might be. ${ }^{133}$ At the same time, the analysis should consider what sort of checks between other interacting authorities might contribute to securing judicial independence. The answers may well differ for each type of IC.

\footnotetext{
${ }^{131}$ Ibid., p. 362.

132 A. Peters, 'The Merits of Global Constitutionalism', 16 Indiana Journal of Global Legal Studies (2009), p. 397-411, 397.

${ }^{133}$ A. Torres Pérez, in M. Bobek (ed.), Selecting Europe’s Judges, p. 187.
} 
Indeed, a number of legal and political constraining mechanisms are already in place, which tend to be controlled by state governments. ${ }^{134}$ In turn, constraints on the action of state governments on constitutional (or other) grounds in the international sphere tend to be scarce. ${ }^{135}$

The forms of institutional dependence and the relevant actors are myriad: state governments have the power to amend the treaties that create and regulate the composition and jurisdiction of ICs; they have a main role in the process of judicial selection and have the power to execute court rulings. Also, there are other sources of dependence, such as the political institutions of the international organizations in which ICs operate, which might be granted the power to appoint judges, to approve the court's budget and the salary of judges and other ICs and domestic courts. ${ }^{136}$

For instance, judicial selection tends to be assigned to state governments, which nominate the candidates and elect or appoint them in the corresponding intergovernmental body. The process of judicial selection in ICs tends to be highly politicized. ${ }^{137}$ Judicial selection is usually regarded as an instrument in the hands of state governments that jeopardizes judicial independence. Nonetheless, there might be good reasons to attribute the power of judicial selection to state governments from the perspective of checks and balances. ${ }^{138}$ The key question is how this power is used, since governments might be tempted to use this power to appoint loyal judges who will advance partisan interests, and whether there are appropriate checks on the executive to balance its power. Constraints on the executive might come from the national sphere, such as parliamentary commissions or fair and transparent procedures for nominating the candidates; or the international one, such as advisory expert panels, or open hearings. The participation of multiple actors in the process of selection potentially enhances judicial independence, since it creates incentives for mutual control. ${ }^{139}$

Also, regarding the enforcement of ICs' judgments, since ICs lack coercive powers, they will need the collaboration of state governments. If ICs can anticipate noncompliance, let alone a political backlash leading to treaty override or even withdrawal from the system, this might distort free decision-making. At the same time, the picture

\footnotetext{
${ }^{134}$ T. Ginsburg, in C.P.R. Romano, K.J. Alter and Y. Shany (eds.), The Oxford Handbook of International Adjudication.

${ }^{135}$ M. Bohlander, in S. Shetreet and C. Forsyth (eds.), The Culture of Judicial Independence, p. 271.

${ }^{136}$ A. Torres Pérez, MPIL Research Paper Series 3 (2017).

${ }^{137}$ R. Mackenzie et al., Selecting International Judges: Principle, Process, and Politics.

${ }^{138}$ A. Torres Pérez, in M. Bobek (ed.), Selecting Europe’s Judges, p. 188-190.

139 J. Melton and T. Ginsburg, 'Does De Jure Judicial Independence Really Matter? A Reevaluation of Explanations for Judicial Independence’, 2 Journal of Law and Courts (2014), p. 187-217.
} 
is a more complex one, since there are other institutions, such as domestic courts, that also play a role in this context, and might collaborate with ICs to enhance the effectiveness of their judgments. ${ }^{140}$ Thus, forms of dependence on other institutions contribute to downplaying the leverage of state governments.

The forms of interdependence among ICs and other national and international institutions will vary across courts. The principle of checks and balances provides a regulative ideal to critically examine current legal and political constraints, and to frame proposals for institutional design to achieve a better balance.

\section{§5. Concluding Remarks}

In the context of the growing institutionalization of ICs, judicial independence becomes a necessary condition for their legitimacy. At the same time, there is no single model of judicial independence that will apply to all ICs, and judicial independence cannot be understood in absolute terms, ${ }^{141}$ since the optimal degree of independence might vary according to the functions and type of ICs.

In the preceding pages, I drew the main lines of an analytical framework of international judicial independence in order to assess, critically examine and guide institutional design and practice. ICs are placed in a complex institutional setting and thus our analysis needs to embrace a variety of actors and variables from a multilevel perspective. In addition to state governments, international political actors, national and international courts, the litigant, and actors of the civil society might become sources of dependence regarding the several dimensions identified: structural, personal, procedural, organizational and compliance. In this field, it is important to combine the legal analysis with insights from the political science and sociological approaches to ICs in order to better understand the threats to judicial independence and the operationalization of the legal rules in practice.

The notion of interdependence captures the need for ICs to be able to make decisions free from external pressures yet at the same time remain subject to certain constraints under the principles of accountability, transparency and checks and balances. Mechanisms of accountability tend to be limited in terms of the consequences and they

\footnotetext{
${ }^{140}$ A. Nollkaemper, 'Conversations among courts: Domestic and International Adjudicators', in C.P.R. Romano, K.J. Alter and Y. Shany (eds.), The Oxford Handbook of International Adjudication.

${ }^{141}$ O.M. Fiss, 'The Right Degree of Independence', in I.P. Stotzky (ed.), Transition to Democracy in Latin America: The Role of the Judiciary (Westview Press, 1993).
} 
are mainly in the hands of judges themselves. Their relative weakness might be justified to avoid jeopardizing independence. At the same time, there has been an effort to specify the standards regarding independence, impartiality and diligence, particularly in younger courts, such as the ICC, while a well-established one, such as the CJEU, has recently amended its code of conduct. Also, there is an increasing demand on the transparency of ICS, which might actually bolster ICs' independence from state governments, by making courts more open to other actors.

Finally, although the tripartite separation of powers is not replicated in the international sphere, ICs do not operate in isolation. They are already embedded in a broader institutional setting conformed by national, supranational and international authorities. The checks and balance principle provides an analytical tool to critically assess the mechanisms in the hands of diverse actors to constrain the action of ICs and the forms that those mechanisms might take, to conclude whether a balance is achieved. In the end, diverse forms of interdependence may well contribute to the overall legitimacy of ICs. 